\title{
Application of Environment-Friendly Rhamnolipids against Transmission of Enveloped Viruses Like SARS-CoV2
}

\author{
Ling Jin ${ }^{1,2, * \mathbb{C}}$, Wendy Black $^{1}$ and Teresa Sawyer ${ }^{3}$ \\ 1 Department of Biomedical Sciences, Carlson College of Veterinary Medicine, Oregon State University, \\ Corvallis, OR 97331, USA; wendy.black@oregonstate.edu \\ 2 Department of Microbiology, College of Science, Oregon State University, Corvallis, OR 97331, USA \\ 3 Electron Microscopy Facility, 145 Linus Pauling Science Center, Oregon State University, Corvallis, \\ OR 97331, USA; SawyerT@Science.oregonstate.edu \\ * Correspondence: ling.jin@oregonstate.edu; Tel.: +1-541-737-9893
}

check for updates

Citation: Jin, L.; Black, W.; Sawyer, T. Application of Environment-Friendly Rhamnolipids against Transmission of Enveloped Viruses Like SARS-CoV2. Viruses 2021, 13, 322. https://doi.org/10.3390/v13020322

Academic Editor:

Kenneth Lundstrom

Received: 25 December 2020

Accepted: 18 February 2021

Published: 20 February 2021

Publisher's Note: MDPI stays neutral with regard to jurisdictional claims in published maps and institutional affiliations.

Copyright: (c) 2021 by the authors. Licensee MDPI, Basel, Switzerland. This article is an open access article distributed under the terms and conditions of the Creative Commons Attribution (CC BY) license (https:/ / creativecommons.org/licenses/by/ $4.0 /)$.

\begin{abstract}
In the face of new emerging respiratory viruses, such as SARS-CoV2, vaccines and drug therapies are not immediately available to curb the spread of infection. Non-pharmaceutical interventions, such as mask-wearing and social distance, can slow the transmission. However, both mask and social distance have not prevented the spread of respiratory viruses SARS-CoV2 within the US. There is an urgent need to develop an intervention that could reduce the spread of respiratory viruses. The key to preventing transmission is to eliminate the emission of SARS-CoV2 from an infected person and stop the virus from propagating in the human population. Rhamnolipids are environmentally friendly surfactants that are less toxic than the synthetic surfactants. In this study, rhamnolipid products, 222B, were investigated as disinfectants against enveloped viruses, such as bovine coronavirus and herpes simplex virus 1 (HSV-1). The $222 \mathrm{~B}$ at $0.009 \%$ and $0.0045 \%$ completely inactivated 6 and $4 \log$ PFU/mL of HSV-1 in 5-10 min, respectively. 222B at or below $0.005 \%$ is also biologically safe. Moreover, $50 \mu \mathrm{L}$ of $222 \mathrm{~B}$ at $0.005 \%$ on $\sim 1 \mathrm{~cm}^{2}$ mask fabrics or plastic surface can inactivate $\sim 10^{3}$ PFU HSV-1 in 3-5 min. These results suggest that $222 \mathrm{~B}$ coated on masks or plastic surface can reduce the emission of SARS-CoV2 from an infected person and stop the spread of SARS-CoV2.
\end{abstract}

Keywords: rhamnolipids; 222A; 222B; HSV-1; HSV-1-GFP; coronavirus; bovine coronavirus

\section{Introduction}

Enveloped viruses, such as coronaviruses, influenza viruses, and herpesviruses, are all wrapped with a phospholipid bilayer called the envelopes. Viral envelopes are cellular phospholipids, which are taken from the infected cell during the budding process. Surfactants are amphiphilic organic compounds comprised of a hydrophobic non-polar hydrocarbon tail and a hydrophilic polar head. They possess an aqueous solubility in the micro- or millimolar range [1]. The compatibility of the hydrophobic tails with phospholipid bilayer allows surfactants to penetrate through the membrane easily in small aqueous range, consequently change the conformation of phospholipid bilayer membrane or the envelope, and separate the membrane lipids. Therefore, the interaction between the phospholipid bilayer and the surfactant has detrimental effect on integrity of enveloped virions (complete viral particle). Enveloped viruses have glycoproteins on their surfaces which act as host receptor binding proteins. If enveloped viruses lose their envelopes, they will lose their glycoproteins. Therefore, viruses without envelopes will not bind to the host receptors and infect their target cells. If the integrity of the viron's envelopes is lost, there is a loss in ability to enter the target cells, and subsequent loss of infectivity. Therefore, the surfactants can be used to kill or inactivate enveloped viruses.

Commercial bleach products, such as Clorox, Lysol, are commonly used to disinfect enveloped viruses in research labs and medical facilities. They are synthetic detergents 
or surfactants and can cause skin irritation or harm the environment. Rhamnolipids are biosurfactants, which are of biological origin and have many advantages over synthetic counterparts, such as low toxicity and high biodegradability [2-4]. Rhamnolipids were first identified in 1949 and purified in 1968 [5,6]. Since then, numerous microorganisms, including bacteria, fungi, and yeast, have been reported to produce rhamnolipids [7-9]. The rhamnolipid structure is determined by the number of rhamnoses (one or two), fatty acids (one or two) and the fatty acid composition. Therefore, rhamnolipids are commonly classified into two groups: Monorhamnolipids and dirhamnolipids. Rhamnolipids have been used as an emulsifier, stabilizer, solubilizer, wetting, foaming agent, bactericide and fungicide [10-18].

Similar to SARS-CoV2, bovine coronavirus (BCoV) is a member of the Coronaviridae family, which comprises enveloped positive-sense single-stranded RNA viruses. BCoV is a pneumoenteric virus that infects the upper and lower respiratory tract, and intestine. Infection of $\mathrm{BCoV}$ can cause calf diarrhea, winter dysentery, and respiratory infections in cattle of various ages [19]. Human herpesvirus type 1 (HSV-1) is a member of the Herpesviridae family that include a large number of enveloped DNA viruses common in both animal and humans. HSV-1 is the cause of cold sores or fever blisters in or around the mouth and encephalitis in newborns [20,21]. It is also the leading cause of corneal blindness in developing countries [22,23]. Both are enveloped viruses, and their surface proteins on the envelopes are essential for virus entry in infection. Rhamnolipids have been shown to be capable of inactivating both bacteria and fungi [24-26]. In this study, the ability of rhamnolipids to inactivate BCoV and HSV-1 was investigated.

\section{Materials and Methods}

\subsection{Surfactants}

Rhamnolipids are provided by AGAE Technologies, LLC (Corvallis, Oregon, USA). AGAE0222A is a $10 \%$ aqueous solution made with commercially available di-rhamnolipid predominant product R95Dd. AGAE0222B is a 10\% aqueous solution made with commercially available mono-rhamnolipid predominant product R95Md. Both rhamnolipid solutions were adjusted to $\mathrm{pH7.4} \pm$ 0.1. In this study, rhamnolipids AGAE0222A and AGAE0222B are called 222A, and 222B, respectively. Sodium dodecyl sulfate (SDS) (EM7910) and Triton X-100 (X-100) were purchased from OmniPur and Sigma-Aldrich, respectively.

\subsection{Viruses and Cells}

HSV-1 McKrae [27] and HSV-1-GFP [28] were cultured in Vero cells in Eagle's Minimum Essential Medium (EMEM) supplemented with 5\% fetal bovine serum (FBS) (GeminiBio, Sacramento, CA, USA), penicillin $(100 \mathrm{U} / \mathrm{mL})$, and streptomycin $(100 \mu \mathrm{g} / \mathrm{mL})$ (Sigma-Aldrich, Inc., St. Louis, MO, USA). Vero cells were cultured in EMEM supplemented with $10 \%$ fetal bovine serum (FBS) (GeminiBio, USA), penicillin $(100 \mathrm{U} / \mathrm{mL})$, and streptomycin $(100 \mu \mathrm{g} / \mathrm{mL})$ (Sigma-Aldrich, Inc., St. Louis, MO, USA) at $37^{\circ} \mathrm{C}$ with $5 \%$ $\mathrm{CO}_{2}$ in a humidified incubator as we described previously [22,29].

Bovine coronavirus (BCoV) was the NADL-Nebraska Strain isolated by the National Veterinary Services Laboratories (NVSL) in 1981 [30]. BCoV was grown on human rectal tumor (Hrt-18G) cells [30,31], which were maintained in EMEM supplemented with 10\% FBS (GeminiBio, USA), penicillin $(100 \mathrm{U} / \mathrm{mL}$ ) and streptomycin $(100 \mu \mathrm{g} / \mathrm{mL})$ (SigmaAldrich, Inc.) at $37^{\circ} \mathrm{C}$ with $5 \% \mathrm{CO}_{2}$ in a humidified incubator. The virus was propagated in EMEM supplemented with $2.5 \mu \mathrm{g} / \mathrm{mL}$ trypsin and $2.5 \mu \mathrm{g} / \mathrm{mL}$ pancreatin, $1 \times$ insulintransferrin-selenium (Cat No. 51500-056, GIBCO) [31].

\subsection{Rhamnolipid Cytotoxicity Assay In Vitro}

Ninety-six-well plates were seeded with $\sim 2 \times 10^{4}$ Vero cells or Hrt-18G cells per well and grown overnight at $37^{\circ} \mathrm{C}$ and $5 \% \mathrm{CO}_{2}$. The cells were washed once with phosphatebuffered saline (PBS) and treated in $100 \mu \mathrm{L} 222 \mathrm{~A}$ or 222B with indicated concentrations 
diluted in PBS at $37^{\circ} \mathrm{C}$ for $1 \mathrm{~h}$. The rhamnolipid-treated cells were then washed once with PBS and then replenished with EMEM containing 5\% FBS (GeminiBio, USA) and antibiotics (as described above), and further incubated for $24 \mathrm{~h}$. After incubation, cell morphology was examined under an inverted light microscope, and cell viability was examined by using colorimetric cell viability kit III (XTT) (PromoKine, Huissen, Netherlands). Briefly, $50 \mu \mathrm{L}$ of the XXT reaction solution was added to each well, and the plate was incubated at $37^{\circ} \mathrm{C}$ incubator for 3-4 h. Absorbance at a wavelength of $450-500 \mathrm{~nm}$ was read on a microplate fluoresce reader (BioTek, Winoosk, VT, USA) and recorded. Wells containing $222 \mathrm{~A}$ or $222 \mathrm{~B}$ at each concentration in media without cells served as a blank to ensure that rhamnolipids themselves were not registering fluorescence [22]. In addition, the toxicity of SDS and Triton-X100 was examined similarly as 222B.

\subsection{HSV-1 and BCoV Infection In Vitro in the Presence or Absence of Rhamnolipids}

Twelve-well plates were prepared the day before infection by seeding each well with approximately $1 \times 10^{5}$ Vero cells or Hrt18G cells. The cells were washed once with PBS and infected with $100 \mu \mathrm{L}$ of either $\sim 2 \times 10^{7} \mathrm{PFU} / \mathrm{mL}$ of HSV-1-GFP or $\sim 1 \times 10^{7} \mathrm{TCID}_{50} / \mathrm{mL}$ of $\mathrm{BCoV}$ in the presence or absence of rhamnolipids. Following 1-hr absorption, the cells were replenished with $1 \mathrm{~mL}$ culture medium containing 5\% FBS and antibiotics (as described above) in the presence or absence of 222B at the indicated concentration. At 24 or $72 \mathrm{~h}$ post-infection (hpi), the cytopathic effect (CPE) from virus infection was examined under an inverted light microscope or fluorescent microscope.

\subsection{Immunoflorescence Staining}

Hrt-18G cells infected with BCoV were washed with ice-cold PBS twice and fixed in $1 \mathrm{~mL}$ ice-cold methanol at $-20{ }^{\circ} \mathrm{C}$ for $20 \mathrm{~min}$. Following fixation, the plates were washed again twice with cold PBS and blocked in $1 \%$ bovine serum albumin (BSA) in Tris-buffered saline (TBS) at room temperature for $1 \mathrm{~h}$, then stained with 1:40 diluted anti-BCoV monoclonal antibody conjugated with Fluorescein isothiocyanate (FITC) at room temperature for $1 \mathrm{~h}$ on a rocker and washed twice with PBS before viewing under fluoresce microscope.

\subsection{Electron Microscopy of Virions}

Six $75-\mathrm{cm}^{2}$ flasks seeded with $90 \%$ confluent Vero cells were infected with 0.01 M.O.I. HSV-1-McKrae. The infected flasks were harvested when 80-90\% CPE developed at 3-4 days post-infection (dpi), and subjected to two-freeze and thaw cycles between $-80{ }^{\circ} \mathrm{C}$ and room temperature. The supernatant was cleared of cells and cell debris by centrifugation at $9000 \times g$ for $30 \mathrm{~min}$ at $4{ }^{\circ} \mathrm{C}$. The virions were then centrifuged through a $60 \%$ sucrose cushion in a Beckman Model XL-70 ultracentrifuge at 25,000 rpm for 1h in a SW28 rotor at $4{ }^{\circ} \mathrm{C}$, as we described previously [32]. The virion pellets were suspended in $100 \mu \mathrm{L} \mathrm{dH} 2 \mathrm{O}$ first, and then $10 \mu \mathrm{L}$ of virion was mixed with $90 \mu \mathrm{L}$ of $0.01 \%$ SDS, $0.01 \%$ Triton $\mathrm{X}-100$, and $0.01 \% 222 \mathrm{~B}$, respectively. The treated virions were stained as we described previously [32]. Briefly, treated virion suspensions were adsorbed to formvar-coated carbon-stabilized copper grids by floating grids on $\sim 20 \mu \mathrm{L}$ drops of the sample spotted on parafilm. The grids were then blotted dry with Whatman filter paper and immediately floated on $\sim 20 \mu \mathrm{L}$ drops of $2 \%$ phosphotungstic acid (PTA) ( $\mathrm{pH} 6.9$ ) in water for $30 \mathrm{~s}$. Excess PTA was removed by side-blotting and the grids were allowed to air dry [32]. Images were obtained with a FEI Titan 80-200/ChemiSTEM Transmission Electron Microscope (TEM).

\subsection{HSV-1 Plaque Reduction Assay Following Rhamnolipid Treatment}

Vero cells were seeded in 12-well tissue culture plates at approximately $2 \times 10^{5}$ cells/well on the day before infection. Three wells were infected with HSV-1 at different concentrations, ranging from $1 \times 10^{3}$ to $1 \times 10^{7} \mathrm{PFU} / \mathrm{mL}$, in the presence or absence of rhamnolipids, 222B. Following a 1 -h viral absorption, $3 \mathrm{~mL}$ of $2 \%$ methylcellulose overlay media was added to each well. Plates were incubated at $37{ }^{\circ} \mathrm{C}$ with $5 \% \mathrm{CO}_{2}$ in a humidified 
incubator for $4-5$ days. The plates were fixed in $20 \%$ methanol, stained with $1 \%$ crystal violet, plaques were counted as described previously [22].

\subsection{Plastic Surface Coating with 222B and Surface-Contact Assay}

The 48-well Corning Costar Flat Bottom Cell Culture Plate with a growth area of $0.95 \mathrm{~cm}^{2}$ was selected for 222B coating on the plastic surface. The bottom of the well was coated by adding $20 \mu \mathrm{L}$ of $222 \mathrm{~B}$ at $0.005 \%$ directly, which covers the entire surface of the well. The coated wells were air-dried overnight. Virus droplets in $10 \mu \mathrm{L}$ containing $10^{3}$ or $10^{4}$ virions (PFU) of HSV-1 were added to the bottom of the well for $1 \mathrm{~min}$ or $5 \mathrm{~min}$. The contact between HSV-1 and 222B coated plastic surface was stopped by adding $1 \mathrm{~mL}$ of PBS elution buffer. Viruses left on the plastic surface were eluted in $1 \mathrm{~mL}$ PBS for $1 \mathrm{~h}$ at room temperature on a plate rocker. The control wells were coated with PBS only. The non-surface contact controls were 222B coated wells, the viruses in $10 \mu \mathrm{L}$ were added to the coated wells after application of $1 \mathrm{~mL}$ PBS elution buffer, therefore, had no direct contact with the coated surface. $250 \mu \mathrm{L}$ of eluted viruses from each well were then titrated by standard plaque assay.

\subsection{Fabric Coating with $222 B$ and Surface-Contact Assay}

Approximately $1 \mathrm{~cm}^{2}$ square fabrics were cut from a commercial surgical mask, made of non-woven fabric (Tronex Healthcare, Mount Olive, NJ, USA), and then soaked in $50 \mu \mathrm{L}$ of $0.005 \% 222 \mathrm{~B}$ or PBS. The soaked fabrics were air-dried overnight after removing the excess liquid from the soaked fabrics. The dried fabrics were then placed in a well of 24-well plate (Corning, Glendale, AZ, USA). Virus droplets in $10 \mu \mathrm{L}$ containing $10^{3}$ or $10^{4}$ PFU HSV-1 were added to the coated fabrics for 3-5 min. The contact between viruses and 222B coated fabrics was stopped by adding $1 \mathrm{~mL}$ PBS elution buffer directly to the well. Viruses left on the fabric surface were eluted at room temperature for $1 \mathrm{~h}$ on a plate rocker. The non-surface contact controls were $222 \mathrm{~B}$ coated fabric, the viruses in $10 \mu \mathrm{L}$ were added onto the fabrics after application of $1 \mathrm{~mL}$ PBS elution buffer, therefore, had no direct contact with the coated fabrics. The mock controls were viral droplets added directly to $1 \mathrm{~mL}$ PBS in wells that were not coated. The eluted viruses were then titrated by standard plaque assay.

\subsection{Statistics}

All statistical analyses were performed using GraphPad Prism version 4 for Windows (GraphPad Software, San Diego, CA, USA). Cell viability results and plaque reduction results were analyzed by two-way ANOVA with Bonferroni post tests.

\section{Results}

\subsection{The Rhamnolipid Treatment Effect on HSV-1 and Coronavirus (BCoV) Replication In Vitro}

The antiviral effect of rhamnolipids, monorhamnolipids (222B) and dirhamnolipids (222A) were first examined against HSV-1. About $2 \times 10^{7} \mathrm{PFU} / \mathrm{mL}$ of HSV-1 was diluted (10 fold) in PBS containing $0.009 \%$ or $0.001 \%$ of $222 \mathrm{~B}$ or $222 \mathrm{~A}$ first, then inoculated to a 12 -well plate seeded with Vero cells. Vero cells are susceptible to HSV-1 infection in vitro and produce visible morphology change (cytopathic effect) at $24 \mathrm{~h}$ post-infection. If the rhamnolipids can kill the virus, then no cytopathic effect (CPE) will be produced in HSV-1 infected cells. Figure 1 shows the cells infected with HSV-1 in the presence or absence of rhamnolipids. In the absence of rhamnolipids, $90 \%$ cytopathic effect (CPE) was observed at $24 \mathrm{~h}$ post-infection (hpi) (Figure 1, HSV-1 only). In the presence of $0.001 \% 222 \mathrm{~A}$ or 222B, 80-90\% CPE was also observed, which was similar to infection in HSV-1 only at 24 hpi. In the presence of $0.009 \% 222 \mathrm{~A}$, only $20-30 \%$ CPE was visible at $24 \mathrm{hpi}(\mathrm{HSV}-1+222 \mathrm{~A}$ ). However, in the presence of $0.009 \%$ 222B (HSV-1+222B), no CPE was observed at $24 \mathrm{hpi}$, which is similar to cells without infection at $24 \mathrm{hpi}$. This suggests that rhamnolipids have antiviral effects against enveloped viruses HSV-1. Since $0.009 \%$ 222B had better protection against HSV-1 infection than 222A did, 222B is selected for the remaining study. 


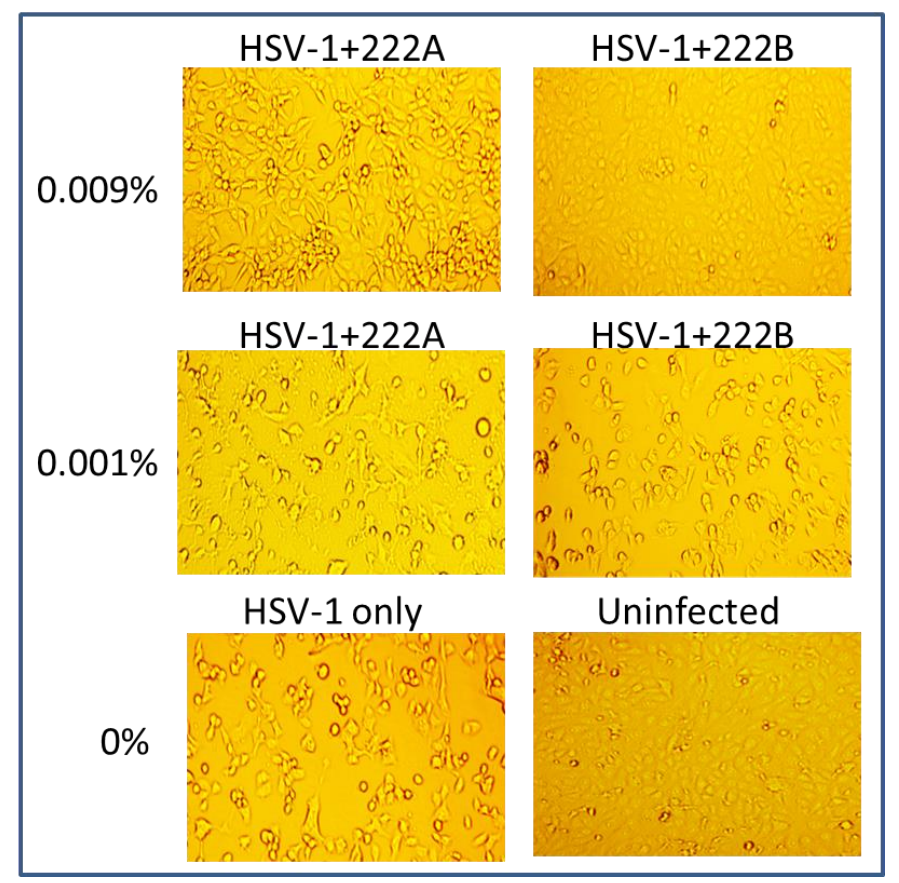

Figure 1. HSV-1 infected Vero cells in the presence or absence of rhamnolipids. The concentration of rhamnolipids is indicated on the left of the images. HSV-1 infection with 222A or 222B is labeled above the image as HSV-1+222A or HSV-1+222B. Vero cells were infected with $\sim 2 \times 10^{6} \mathrm{FPU} /$ well, and the images were taken at $24 \mathrm{hpi}$ at $10 \times$ magnification.

To prove the rhamnolipid's anti-viral activity is not HSV-1 specific but specific to enveloped viruses, $222 \mathrm{~B}$ was tested against bovine coronaviruses $(\mathrm{BCoV})$ infection in vitro. Hrt-18G cells are susceptible to $\mathrm{BCoV}$ infection in vitro and produce visible morphology change (cytopathic effect) at $72 \mathrm{~h}$ post-infection. If the rhamnolipids can kill the virus, then no cytopathic effect (CPE) will be produced in BCoV infected cells. Hrt-18G cells in a 12-well plate were infected with $\mathrm{BCoV}$ at $\sim 1 \times 10^{6} \mathrm{TCID}_{50} /$ well in the presence of $0.009 \%$ or $0.001 \%$ of $222 \mathrm{~B}$. At $72 \mathrm{hpi}$, BCoV CPEs, such as cell rounding, inclusion bodies (black arrows), were visible in cells infected with $\mathrm{BCoV}$ without 222B (Figure $2 \mathrm{~A}, \mathrm{BCoV}$ only). However, in the presence of $222 \mathrm{~B}$ at $0.009 \%$, no CPE was visible in cells infected with $\mathrm{BCoV}$ $(\mathrm{BCoV}+0.009 \%)$. To further confirm the replication of $\mathrm{BCoV}$, infected cells were stained with FITC labeled $\mathrm{mAb}$ specific to $\mathrm{BCoV}$ at $72 \mathrm{~h}$ post-infection. As shown in Figure 2B, positive FITC staining (white arrows) was only visible in wells with $\mathrm{BCoV}$ only and $\mathrm{BCoV}$ infection with $0.001 \%$ 222B. In contrast, no FITC staining was visible in wells infected with $\mathrm{BCoV}$ containing $0.009 \%$ 222B. Noticeably, in the presence of $0.001 \% 222 \mathrm{~B}$, positive $\mathrm{BCoV}$ staining (Green fluoresce, white arrows) is significantly reduced compared to the cells with $\mathrm{BCoV}$ only. This result suggests that rhamnolipids have antiviral effects against enveloped viruses, such as HSV-1 and BCoV. 
A

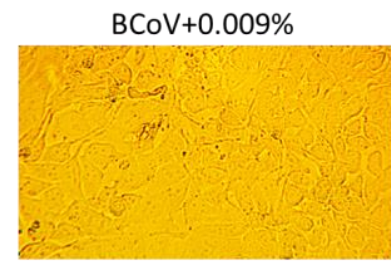

B

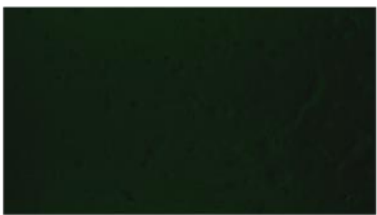

$\mathrm{BCoV}+0.001 \%$
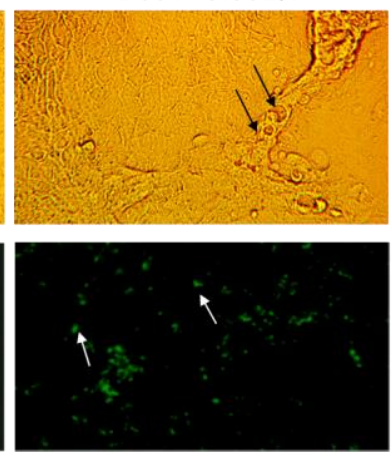

BCoV only
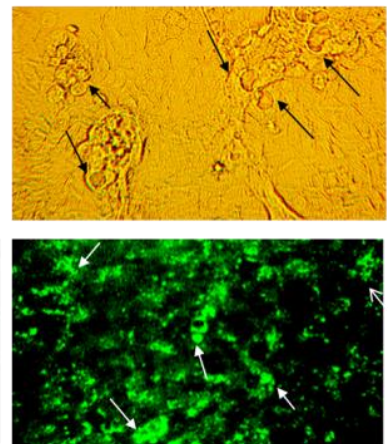

Figure 2. Bright light images and direct immunofluorescence staining of $\mathrm{BCoV}$ infected cells in the presence and absence of 222B. A: Hrt18G cells infected with $\sim 1 \times 10^{6} \mathrm{TCID}_{50}$ of BCoV per well in a 12 -well plate. The concentration of $222 \mathrm{~B}$ is labeled above the images in the $\mathrm{BCoV}$ infection. The bright light images were captured at $72 \mathrm{hpi}$ at $20 \times$ magnification. Black arrows indicate vesicles within the virus-infected cells. B: Hrt18G cells at 72hpi were stained with 1:40 diluted BCoV antibody conjugated with FITC and viewed under the fluorescence microscope. Fluorescent images were captured at $10 \times$ magnification. White arrows indicate FITC stained BCoV antigens within the infected cells.

\subsection{Cytotoxicity of Rhamnolipids In Vitro}

To fully understand how rhamnolipids inactivate the enveloped viruses, we need to ensure that the concentration of rhamnolipids used in our study has no cytotoxicity to the cells. Only viable cells can support the virus replication in vitro. Therefore, cell cultures are exposed to different concentrations of rhamnolipid for $60 \mathrm{~min}$ in the cytotoxicity assay. To determine whether rhamnolipids affect cell viability, Vero cell and Hrt-18G cell viability were tested under different concentrations of rhamnolipids by colorimetric cell viability kit III (XTT). The assay is based on the ability of mitochondria enzyme from metabolic active cells to reduce the tetrazolium salt XTT to orange-colored formazan compounds. The dye formed is water-soluble, and its intensity is proportional to the number of metabolically active cells. The greater the number of active cells in the well, the greater the activity of mitochondria enzymes, the higher the concentration of the dye formed, the higher absorbance on the ELISA reader. As shown in Figure 3A, Vero cells treated with rhamnolipids, $222 \mathrm{~A}$ and $222 \mathrm{~B}$, at or above $0.05 \%$, had less than $10 \%$ viable cells left, compared to the untreated cells (Mock-treated). Cells treated with rhamnolipids 222A at $0.01 \%$ and $0.009 \%$ were over $75 \%$ viable compared to the untreated control, respectively. Cells treated with rhamnolipids $222 \mathrm{~B}$ at $0.01 \%$ and $0.009 \%$ were $\sim 50 \%$ and $\sim 70 \%$ viable, respectively. Vero cells treated with rhamnolipids $222 \mathrm{~A}$ or $222 \mathrm{~B}$ at or below $0.005 \%$ all had over $90 \%$ viable. Therefore, rhamnolipids below $0.005 \%$ is less toxic to cells during direct contact. To compare rhamnolipids 222B to synthetic surfactant, the toxicity of SDS and Triton X-100 was examined in Hrt18-G cells. As shown in Figure 3B, cells treated with $0.005 \%$ of SDS and Triton X-100 had less than $20 \%$ viable cells left, which is significantly more toxic than $222 \mathrm{~B}$ at $0.005 \%$. Therefore, rhamnolipids are less toxic than those synthetic surfactants, such as SDS and Triton X-100. 
A:

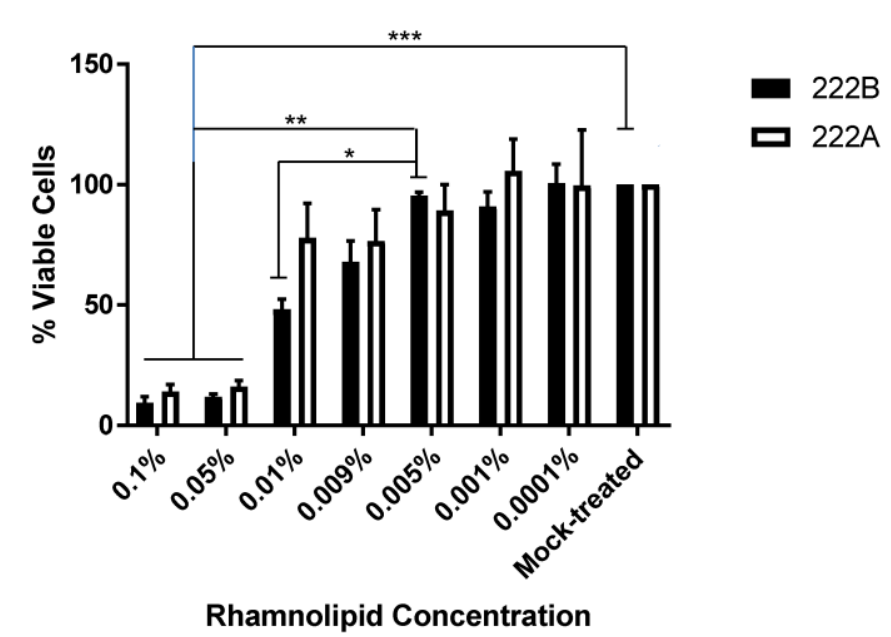

B:

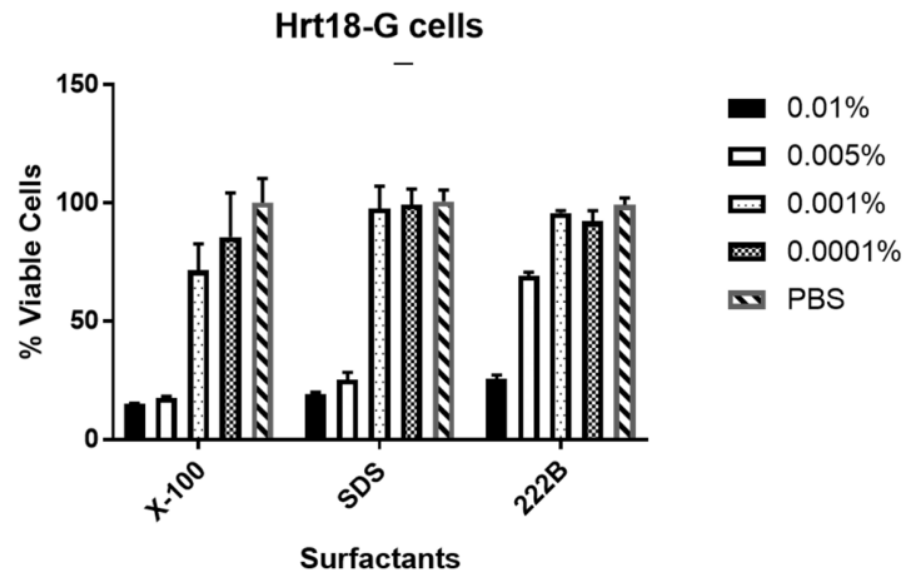

Figure 3. The cytotoxicity of Rhamnolipids in vitro. Vero cells (A) or Hrt-18 G cells (B) were incubated with the indicated concentration of rhamnolipids or surfactants in PBS for $1 \mathrm{~h}$. The treatment was then removed, and the cells were washed twice with PBS and further incubated for $24 \mathrm{~h}$ in EMEM with 5\% serum and antibiotics as described in materials and methods. Cell viability was evaluated with XTT cell viability kit III (PromoKine), which measures metabolic activity based on the extracellular reduction of XTT by NADH produced in the mitochondria, and expressed as a percentage of the Mock-treated control $(n=3)$. A significant statistical difference from the PBS-treated control (Mock-treated) or $0.005 \% 222 \mathrm{~B}$ (A) is marked with ${ }^{*} p<0.05,{ }^{* *} p<0.001,{ }^{* * *} p<0.0001$ (two-way ANOVA with Bonferroni post-test).

\subsection{Comparison of Surfactants against an Enveloped Virus, HSV-1}

To prove that viral envelopes are common targets of surfactants, different surfactants were tested against HSV-1 infection in vitro. An ionic surfactant, sodium dodecyl sulfate (SDS), and a non-ionic surfactant, such as Triton X-100, were investigated here. HSV-1 with GFP expression was used to visualize the replication of HSV-1 directly in vitro. Vero cells seeded in 12 well plates were infected with $\sim 1 \times 10^{5} \mathrm{PFU} /$ well (i.e., $10^{5}$ virions per well) in $0.009 \%$ of SDS, triton X-100, and 222B, respectively. At $24 \mathrm{hpi}$, neither HSV-1 CPE nor GFP expression was observed in the presence of SDS or Triton X-100, or 222B (Figure 4). Around $50 \%$ and $90 \%$ of Vero cells were dead and detached in the presence of SDS, and Triton $\mathrm{X}-100$, respectively. However, no cell death was observed in infected cells in the presence of 222B (Figure 4A, 222B). In line with the observation under the light microscope, no GFP expression was observed in HSV-1 infection in the presence of 222B. GPF expression was only observed in HSV-1only infection without any treatment. This proves SDS and Triton $\mathrm{X} 100$ were too toxic to cells; 222B is much safer biologically than the synthetic surfactants. 


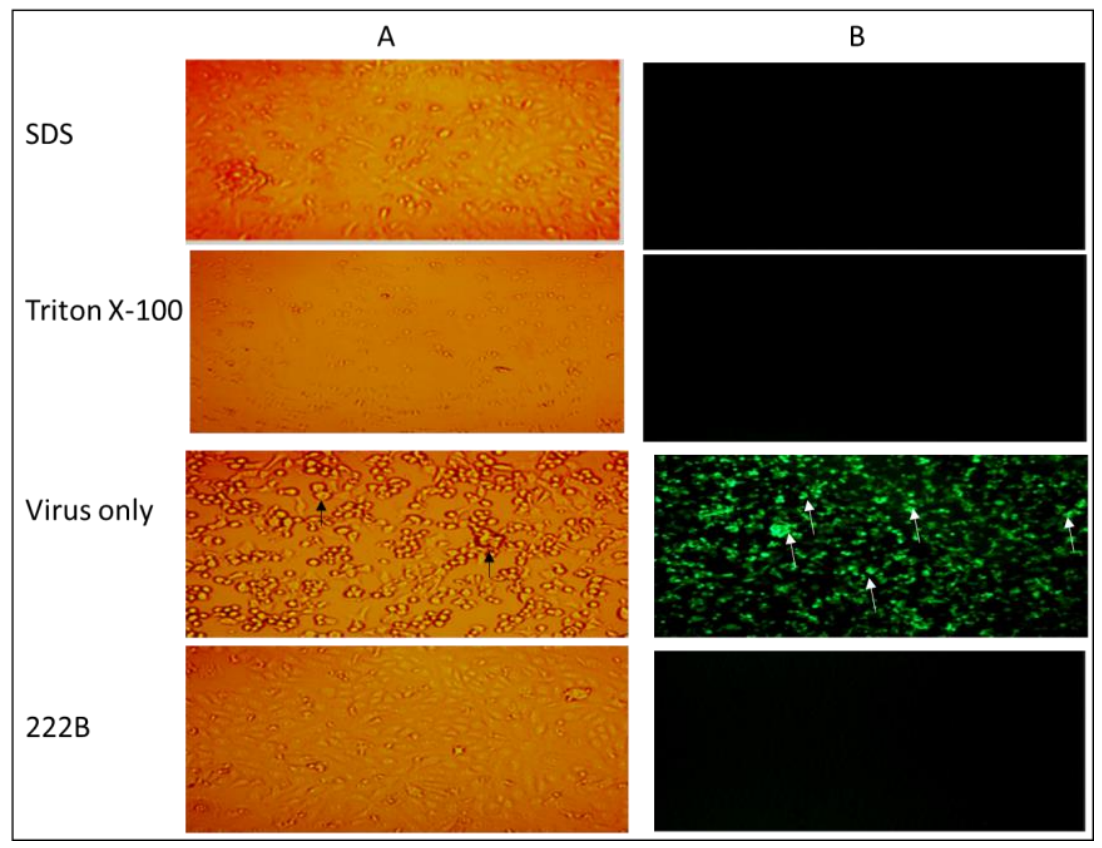

Figure 4. Bright light (A) and fluorescence (B) images of Vero cells infected with HSV-1-GPF. HSV-1GPF at $\sim 1 \times 10^{5}$ PFU/well was inoculated to Vero cells in the presence of SDS, Triton X-100, 222B, and HSV-1 only, respectively. All surfactants were made at $0.009 \% \%$ in the inoculants. A: The bright light image was captured at $10 \times$ magnification. B: Fluorescent images were captured at $20 \times$ magnification. Black arrows indicate CPE under the light microscope, such as cell rounding and aggregation in HSV-1-infected cells. White arrows indicate GFP expression from GFP-HSV-1 replication under the fluorescent microscope.

\subsection{Envelope Integrity in the Presence of Surfactants}

To visualize the effect of surfactants on viral envelopes directly, HSV-1 virions were treated with different surfactants and examined under the transmission electron microscope (TEM). HSV-1 virions, $\sim 1 \times 10^{7} \mathrm{PFU} / \mathrm{mL}$, isolated from both tissue culture supernatant and cell lysates were diluted $1: 10$ by suspending $0.1 \mathrm{~mL}$ of viruses in $0.9 \mathrm{~mL}$ of $\mathrm{H}_{2} \mathrm{O}$ containing $0.01 \%$ of 222B, SDS, and Triton X-100, respectively, before TEM negative staining. Negative staining is a unique technique of "negative contrast" staining; the contrast is not applied to the object but its environment, using heavy metal salts, such as phosphotungstic acid (PTA). The electron beam can cross biological material easier than the surrounding space. The heavy metal staining forms a dark contrast around viral particles (virions) (Figure 5). The enveloped viruses are those virions with a white ring (white arrow) surrounding the capsid (Figure 5, black arrow). In the untreated viral samples, enveloped virions were visible in each view (Figure 5A, white arrows). However, no enveloped virion was visible in samples treated with 222B (Figure 5B). Likewise, fewer enveloped virions were visible in samples treated with SDS (Figure 5C) or Triton X-100 (Figure 5D). This suggests that virion envelopes had fellen apart in the presence of surfactants. Viral proteins on the envelope are essential for virus entry. If the viruses lose their envelopes, they will not be able to bind to the host receptors, consequently, lose their infectivity. 

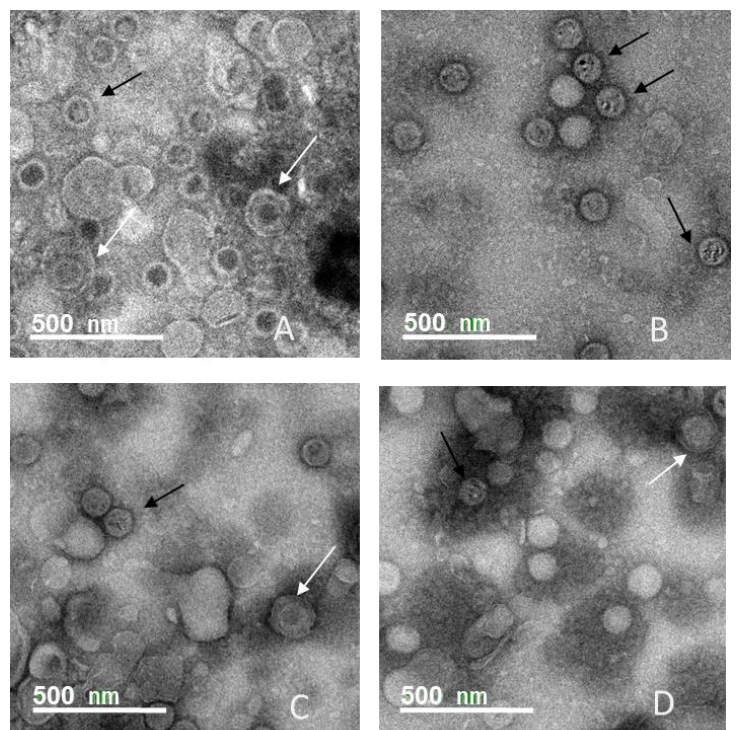

Figure 5. Electron micrograph images of HSV-1 virions treated with different surfactants. The images were HSV-1 virions without treatment (A), virions treated with $0.009 \%$ of $222 \mathrm{~B}(\mathbf{B}), 0.009 \%$ of SDS (C), and $0.009 \%$ of Triton X-100 (D), respectively. The black arrow indicates the capsids of virions without envelopes. The white arrow indicates the envelope of the virion. Scale bar $=0.5 \mu \mathrm{m}$.

To further prove that viral envelopes come apart once in contact with rhamnolipids, $100 \mu \mathrm{L}$ of HSV- 1 viruses at $\sim 1 \times 10^{6} \mathrm{PFU} / \mathrm{mL}$ were diluted in $0.9 \mathrm{~mL}$ PBS containing $0.01 \%$ of 222B or PBS alone and mixed briefly by vortexing, and immediately inoculated to a 12-well plate seeded with $\sim 1 \times 10^{5}$ Vero cells. Figure 6 shows the cells infected with HSV-1 diluted in PBS with or without 222B. No CPE was observed in cells infected with HSV-1 diluted in PBS containing 0.009\% 222B before infection. On the other hand, 80-90 CPE was observed in cells infected with HSV-1 diluted in PBS without 222B, although the culture median contains $0.009 \%$ 222B. Similarly, GFP expression was only observed in cells infected with HSV-1 diluted only in PBS and cultured in media containing 0.009\% 222B (Figure 6, HSV-1 only). This further demonstrated that rhamnolipids 222B acted directly on the surface of vial envelopes. In addition, it suggests that $0.009 \%$ 222B has no effect on HSV-1 replication inside of cells when it is applied to the culture media after HSV-1 infection.
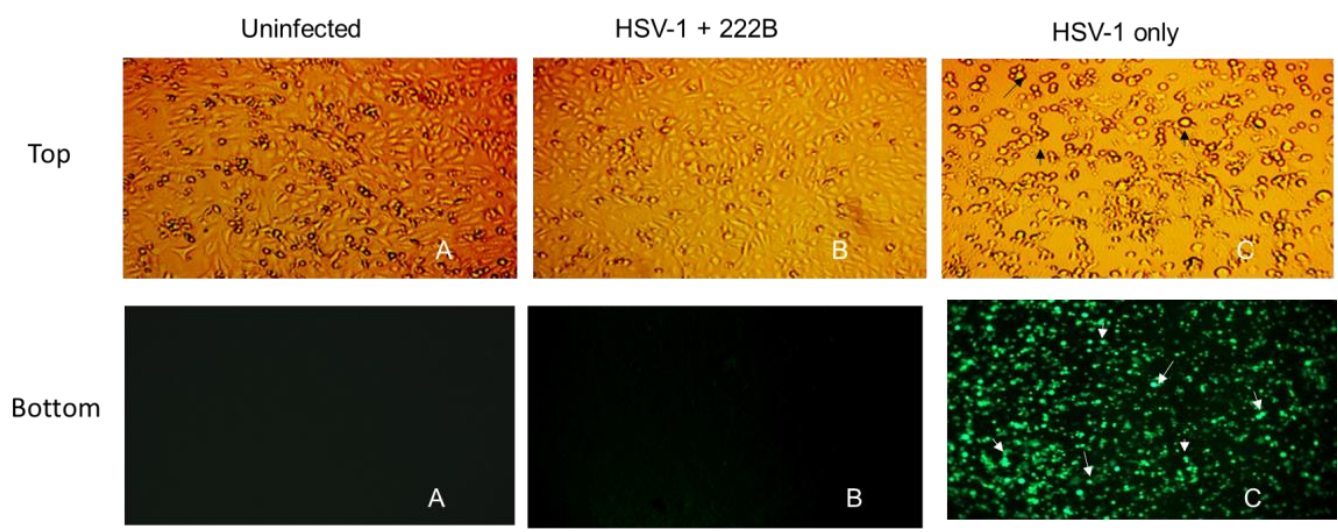

Figure 6. Bright light (Top) and fluorescence (bottom) images (10× magnification) of HSV-1-GFP infection. "HSV-1+222B" represents cells infected with HSV-1 that were diluted with PBS containing $0.009 \% 222 \mathrm{~B}$ and cultured in a media without 222B. "HSV-1 only" represents cells infected with HSV-1 that were diluted with PBS only and cultured in a media containing $0.009 \%$ 222B. Both bright light and fluorescent images were captured at $10 \times$ magnification. Black arrows indicate CPE, such as cell rounding and aggregation in HSV-1-infected cells. White arrows indicate GFP expression from GFP-HSV-1 replication. 


\subsection{B Antiviral Activity against Different Concentrations of HSV-1}

To determine the potency of 222B against enveloped viruses, different concentrations of HSV-1 were treated with different concentrations of 222B before inoculation. The viruses were diluted in different concentrations of 222B first, then titrated immediately by standard plaque assay. Therefore, HSV-1 viruses were only exposed to 222B treatment during the dilution and inoculation stages. The plaque assay was performed in 12-well plates, where only $0.1 \mathrm{~mL}$ diluted viruses were inoculated to each well. Following $1 \mathrm{~h}$ absorption at $37^{\circ} \mathrm{C}$, $2 \mathrm{~mL}$ of overlay media was added to each well. As shown in Figure 7, no viral plaque was observed in wells infected with $\sim 2 \times 10^{6}$ PFU HSV- 1 diluted in $0.009 \% 222 \mathrm{~B}$. Similarly, 222B at $0.0045 \%$ reduced the input virus titer from $\sim 2 \times 10^{6} \mathrm{PFU}$ to $\sim 2 \times 10^{2} \mathrm{PFU}, \sim 2 \times 10^{5} \mathrm{PFU}$ to $10-20 \mathrm{PFU}, \sim 2 \times 10^{4} \mathrm{PFU}$ to a few PFU, respectively. $222 \mathrm{~B}$ at $0.001 \%$ reduced the input virus down to about 10 -fold. However, 222B at a concentration below $0.001 \%$ had little or no antiviral activity. These results demonstrate that $222 \mathrm{~B}$ at $0.0045 \%$ and $0.009 \%$ can inactivate $\sim 1 \times 10^{4}$ and $\sim 1 \times 10^{6} \mathrm{PFU}$ of enveloped viruses, respectively.

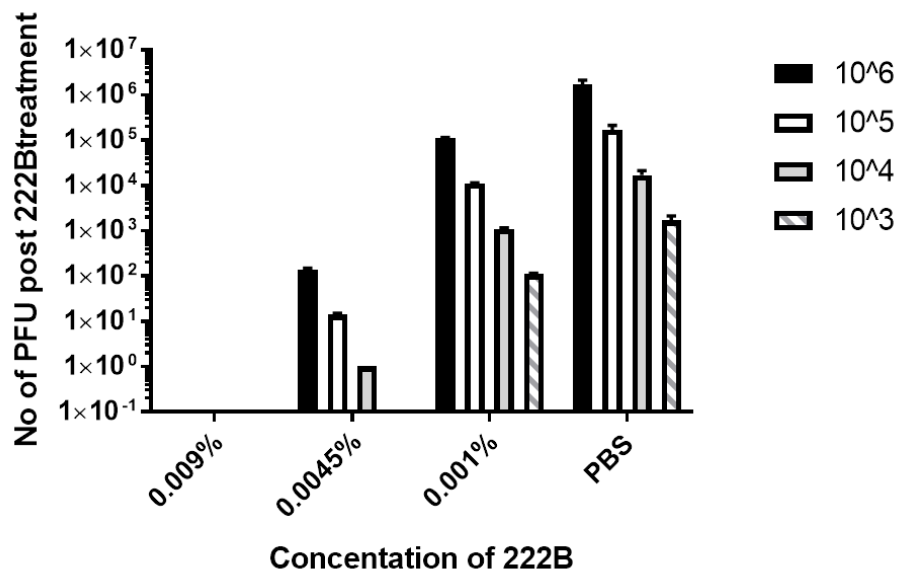

Figure 7. Plaque reduction of 222B against HSV-1. HSV-1 stock at $\sim 2 \times 10^{7} \mathrm{PFU} / \mathrm{mL}$ was diluted to $\sim 2 \times 10^{6} \mathrm{PFU} / \mathrm{mL}$ (solid bar), $\sim 2 \times 10^{5} \mathrm{PFU} / \mathrm{mL}$ (open bar), $\sim 2 \times 10^{4} \mathrm{PFU} / \mathrm{mL}$ (grey bar), $\sim 2 \times 10^{3} \mathrm{PFU} / \mathrm{mL}$ (stripped bar) in PBS containing $222 \mathrm{~B}$ at $0.009 \%$, or $0.005 \%$, or $0.001 \%$ in the final concentration, respectively. The diluted viruses were then titrated in a 12-well plate seeded with Vero cells. Plaque formation was quantified at $4-5 \mathrm{dpi}$ and expressed as average PFU post 222B treatment $(n=3)$.

\subsection{Contact Inhibition against HSV-1 on 222B Coated Plastic Surface}

If a biologically safe antiviral product remains active on a coated surface, we could use it to kill the enveloped viruses and prevent the spread of respiratory viruses, such as SARSCoV2. To this end, 222B anti-HSV-1 activity on the plastic surface was investigated here. The surface of a 48 -well plate, $\sim 1 \mathrm{~cm}^{2}$ per well, was coated with $20 \mu \mathrm{L}$ of $222 \mathrm{~B}$ at $0.005 \%$ and air-dried before testing. Viral droplets in $10 \mu \mathrm{L}$ containing $\sim 2 \times 10^{4}$ or $\sim 2 \times 10^{3} \mathrm{PFU}$ of HSV1 was directly applied to the $222 \mathrm{~B}$ coated surface. The contact between the coated surface and viruses was tested for 1 or $5 \mathrm{~min}$ and then stopped by adding $1 \mathrm{~mL}$ of PBS elution buffer. The post-contact viruses were eluted at room temperature for $1 \mathrm{~h}$ on a plate rocker. If the rhamnolipids can inactivate envelopes on the coated surface, then no infectious viruses or reduced infectious viruses will be eluted. Figure 8 shows the number of HSV-1 PFU detected after direct contact. When $\sim 2 \times 10^{4} \mathrm{PFU}$ HSV- 1 in $10 \mu \mathrm{L}$ was applied to the 222B coated plastic surface, around $200 \mathrm{PFU}$ was detected following 1-min contact, and about $10 \mathrm{PFU}$ was detected following 5-min contact (Figure 8A). Likewise, when $2 \times 10^{3} \mathrm{PFU}$ was applied to the 222B coated plastic surface, about $30 \mathrm{PFU}$ on average were detected in the elution media following 1-min contact; no PFU was detected following 5-min contact (Figure 8B). On the other hand, when $\sim 2 \times 10^{4}$ or $\sim 2 \times 10^{3}$ PFU HSV- 1 in $10 \mu \mathrm{L}$ was applied to the PBS coated surface, similar numbers of PFU were recovered (Figure $8, \mathrm{PBS}$ ). The 
reduction at $5 \mathrm{~min}$ contact $(222 \mathrm{~B}-5 \mathrm{~min})$ is statistically significant compared to untreated control $\left(p<0.0006\right.$ for $2 \times 10^{4}$ PFU HSV-1 per droplet, and $p<0.0002$ for $2 \times 10^{3}$ PFU per droplet). This suggests that rhamnolipids on the plastic surface can kill enveloped viruses.

A:

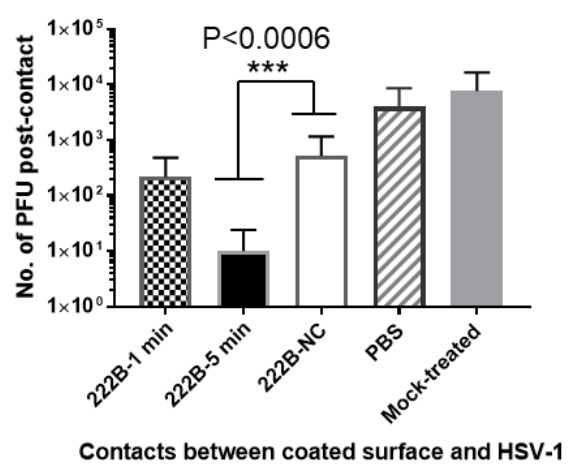

B:

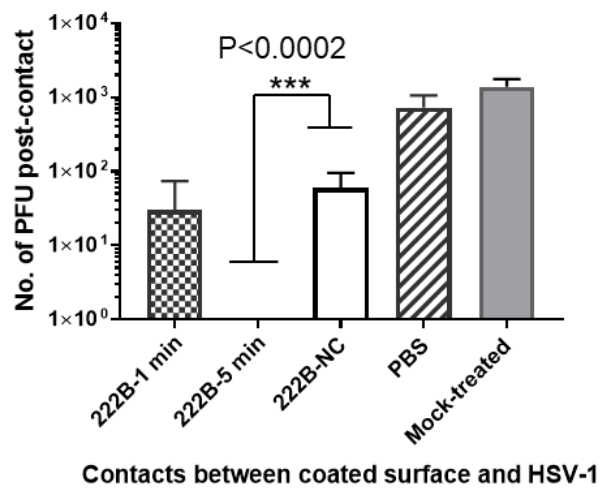

Figure 8. Contact inhibition against HSV-1 on the 222B coated plastic surface. The plastic surface was exposed to input viruses at $\sim 2 \times 10^{4} \mathrm{PFU}(\mathbf{A})$ or $\sim 2 \times 10^{3} \mathrm{PFU}$ (B) per well. The X-axis stands for contacts between coated surface and HSV-1; the Y-axis represents the number of PFU post-contact. The checked bar stands for direct contact between $222 \mathrm{~B}$ and HSV-1 for $1 \mathrm{~min}$ (222B-1 min); the solid bar stands for direct contact between 222B and HSV-1 for 5 min (222B-5 min); the open bar stands for the no direct contact between HSV-1 and 222B (222B-NC), the striped bar stands for direct contact between PBS coated surface and HSV-1 for 5 min (PBS); and the gray bar stands for HSV-1 diluted in PBS directly (Untreated). The viruses eluted after direct contact were quantified by plaque assay as average PFU post 222B treatment $(n=3)$. A significant statistical difference from the 222B-NC is marked with ${ }^{* * *} p<0.0002$ and $p<0.0006$ (two-way ANOVA with Bonferroni post-test).

\subsection{Contact Inhibition against HSV-1 on 222B Coated Fabric Surface within 3-5 min}

To determine whether 222B on the coated surgical mask can inactivate enveloped viruses, about $1-\mathrm{cm}^{2}$ mask fabrics were coated with $50 \mu \mathrm{L}$ of $0.005 \% 222 \mathrm{~B}$ and air-dried before testing. The viral droplets in $50 \mu \mathrm{L}$ were applied directly to the $222 \mathrm{~B}$ coated mask fabric for 3-5 min. The interaction between viruses and 222B on the fabric surface was stopped by adding $1 \mathrm{~mL}$ PBS elution buffer (which will dilute 222B to a concentration with little or no antiviral activity). The post-contact viruses were eluted in $1 \mathrm{~mL}$ PBS at room temperature for $1 \mathrm{~h}$ on a plate rocker. When $1.45 \times 10^{4} \mathrm{PFU}$ per droplet was applied to the 222B coated mask fabric, less than 10 PFU on average were detected in the elution media (Figure 9A). When $1.45 \times 10^{3}$ PFU per droplet was applied to the 222B mask fabric, no viral plaque was detected in the elution media (Figure 9B). In contrast, when $1.45 \times 10^{4}$ PFU per droplet was applied to the 222B coated fabric after application of $1 \mathrm{~mL}$ elution media without direct contact, about $2.9 \times 10^{3}$ PFU was detected in the elution media (Figure 9A, 222B-NC). Likewise, when $1.45 \times 10^{3} \mathrm{PFU}$ per droplet was applied to the coated fabric without direct contact, about $2.2 \times 10^{2}$ PFU was detected in the elution media (Figure 9B, 222B-NC). The reduction from direct contact (222B) is statistically significant compared to non-direct contact (222B-NC) $\left(p<0.00011 .45 \times 10^{4}\right.$ PFU HSV-1 per droplet, and $p<0.0001$ for $2.9 \times 10^{3}$ PFU per droplet). When input viruses at $1.45 \times 10^{4} \mathrm{PFU}$ and $1.45 \times 10^{3}$ PFU per droplet were applied to the PBS coated fabrics, about $2.2 \times 10^{3} \mathrm{PFU} / \mathrm{mL}$ and $2.2 \times 10^{2} \mathrm{PFU} / \mathrm{mL}$ were detected in the elution media, respectively (Figure 9). These results demonstrated that $0.005 \%$ of $222 \mathrm{~B}$ coated on the mask could inactivate about $\sim 1 \times 10^{3}$ PFU enveloped viruses per $\mathrm{cm}^{2}$. 
A:

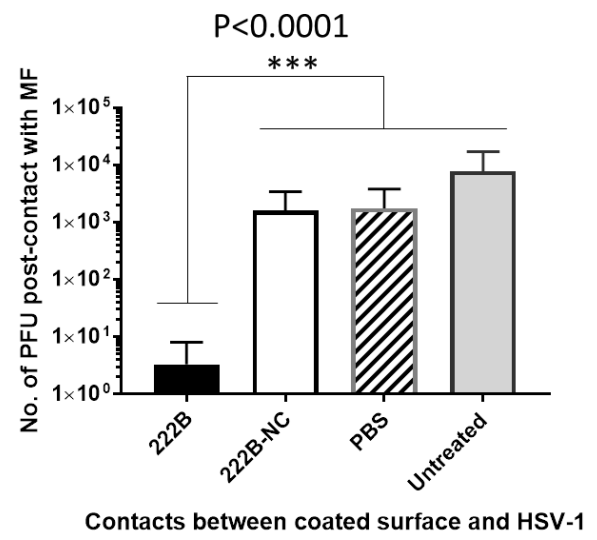

B:

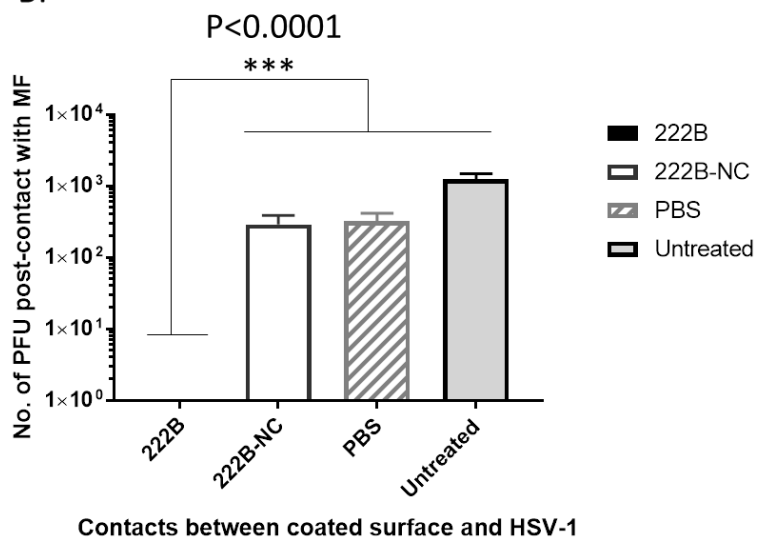

Figure 9. Contact inhibition against HSV-1 on the 222B coated fabric surface within $3-5 \mathrm{~min}$. The mask fabric surface was exposed to input viruses at $\sim 1.45 \times 10^{4} \mathrm{PFU}(\mathbf{A})$ or $\sim 1.45 \times 10^{3} \mathrm{PFU}(\mathbf{B})$ per $\mathrm{cm}^{2}$. The X-axis stands for contacts between coated surfaces and HSV-1; the Y-axis represents the number of PFU post-contact with the coated fabrics. The solid bar stands for direct contact between 222B and HSV-1 (222B); the open bar stands for the no direct contact between HSV-1 and 222B (222B-NC); striped bar stands for direct contact between PBS coated surface and HSV-1 (PBS), and the gray bar stands for HSV-1 diluted in PBS directly (Untreated). The viruses eluted after direct contact were quantified by standard plaque assay as average PFU post 222B contact $(n=3)$. A significant statistical difference from the 222B-NC and PBS control is marked with ${ }^{* * *} p<0.0001$ (two-way ANOVA with Bonferroni post-test).

\section{Discussion}

Rhamnolipids are biosurfactants and have many advantages over synthetic surfactants, such as low toxicity and high biodegradability. In this study, 222B made of predominant monorhamnolipids were found to have better anti-HSV-1 activity than that of predominant dirhamnolipid, 222A (Figure 1). At the same concentration, such as $0.009 \%$, 222B killed more HSV-1 viruses than 222A did (Figure 1, HSV-1+222B). This difference between 222A and 222B could be that 222A has an extra rhamnose sugar group (rha), which may interfere with the interactions between the lipid tail with the phospholipid bilayers of envelopes. Therefore, the monorhamnolipids are better anti-enveloped viral agents.

Like synthetic surfactants, rhamnolipids are toxic to cells when their concentration is at or above $0.05 \%$ (Figure 3). However, comparing to SDS (anionic surfactant) and Triton X-100 (a non-ionic surfactant), rhamnolipids are less toxic at lower concentrations, such as $0.009 \%$ and $0.005 \%$, which are still potent against enveloped viruses. Interestingly, $222 \mathrm{~A}$ is slightly less toxic to Vero cells than 222B when the concentration is below $0.005 \%$ (Figure 3A). This may come from the difference in their structures, where 222A is composed of $95 \%$ of dirhamnolipids, while $222 \mathrm{~B}$ is composed of $95 \%$ of monorhamnolipids. In line with this observation, a similar product $223 \mathrm{~A}$, containing $90 \%$ of dirhamnolipids, is also less toxic than $223 \mathrm{~B}$ consist of $90 \%$ of monorhamnolipids.

The primary action of rhamnolipids against viruses was found to be specific to the envelopes. In the presence of rhamnolipids, such as $222 \mathrm{~B}$, viral envelopes became unstable and fell apart from the capsids. As shown in Figure 5, HSV-1 virion treated with 222B had no envelopes left around the capsids. Also, dense spots on the naked capsids were observed in virions treated with $222 \mathrm{~B}$ (Figure $5 \mathrm{~B}$ ). This suggests that heavy metal staining had gone inside of the capsids. This could mean that the viral capsids were also compromised in the presence of 222B, which suggests that rhamonlipids may have antiviral activities to the non-enveloped viruses too. Although non-enveloped virions were also visible in the untreated sample (Figure 5A), virions, used here, were isolated from tissue culture supernatant and cell lysates, where there are usually many incomplete virions.

The action of rhamnolipids against the envelopes was found to be pretty fast and instantaneous. The time that it takes to dilute the virus samples is between 5-10 min. The diluted viruses were then inoculated to wells seeded with cells immediately. We 
found that viruses at about $\sim 1 \times 10^{6} \mathrm{PFU}$ diluted in $0.009 \%$ 222B lost all their infectivity; produced no CPE in the infected cells (Figure 6, HSV-1+222B). However, when the viruses (also $1 \times 10^{6} \mathrm{PFU}$ ) were inoculated first without diluting in 222B, and the infection was cultured in media containing $0.009 \%$ 222B, HSV-1 replication was not affected (Figure 6, HSV-1 only). These results suggest that 222B damaged the viral envelops during the dilution phase when they directly contacted each other, and rhamnolipids could destabilize the viral envelope within 5-10 min and destroy their infectivity. Once the viruses enter the cell, rhamnolipids have no effect on virus replication inside of the infected cells.

In this study, rhamnolipids' antiviral activity was investigated mostly in concentrations that are less toxic to the cell, such as $0.009 \%$ and $0.005 \%$. Although $0.009 \%$ is relatively low, 222B at this concentration can kill $\sim 1 \times 10^{7} \mathrm{PFU} / \mathrm{mL}$ of HSV- 1 or BCoV. Also at $0.0045 \%, 222 \mathrm{~B}$ can kill $\sim 2 \times 10^{5} \mathrm{PFU} / \mathrm{mL}$ (Figure 7). Therefore, the rhamnolipid anti-enveloped virus activity is potent and dose-dependent; the higher the concentration is, the higher the killing activity is. Not only $222 \mathrm{~B}$ can inactivate enveloped virus in the liquid phase, but it also can kill viruses on the coated surface. As results shown in Figures 8 and 9, 222B on coated plastic and fabric surface could kill HSV-1 applied to the surface directly. $005 \%$ of $222 \mathrm{~B}$ on the mask and plastic surface is capable of killing at least $\sim 1 \times 10^{3} \mathrm{PFU}$ HSV-1 $/ \mathrm{cm}^{2}$ within $5 \mathrm{~min}$ (Figure 8 ), $0.009 \%$ of 222B on the coated mask and plastic surface can kill almost $\sim 1 \times 10^{5} \mathrm{PFU}$ HSV-1/ $\mathrm{cm}^{2}$. Therefore, the killing capacity on the coated surface is also dose-dependent, where the higher the concentration is, the higher the killing activity is.

Respiratory viruses are transmitted mostly via droplets or aerosols, or body secretions, such as tears, nasal or oral discharges. The number of viruses shed in the nasal or oral secretion can range from $10^{4}$ to $10^{7}$ genome copies $/ \mathrm{mL}$ (or $10^{2}$ to $10^{5}$ genome copies/10 uL) depending on the severity of the infection and the types of viruses $[33,34]$. For example, Middle East respiratory syndrome coronavirus (MERS-CoV) is a highly pathogenic coronavirus, can cause $34 \%$ mortality in infected humans [35]. Almost $5 \times 10^{6}$ genome copies $/ \mathrm{mL}$ can be shed in sputum from patients with severe MERS [36]. Severe acute respiratory syndrome coronavirus 2 (SARS-CoV-2) is the virus responsible for the 2019 Coronavirus disease (COVID-19) pandemic. It was estimated that $10^{4}-10^{7}$ genome copies / $\mathrm{mL}$ could be shed in nasal and pharyngeal specimens from COVID-19 patients [34]. Around $10^{4}-10^{5}$ genome copies/mL SARS-CoV2 could be shed in sputum from severely infected COVID-19 patients [37,38]. In the case of Influenza A virus infection, $10^{4}-10^{7}$ virions $/ \mathrm{mL}$ could be shed from patients with uncomplicated acute influenza $\mathrm{A}$ [33]. If these respiratory viruses came out in a $10 \mu \mathrm{L}$ droplet size, there would be $10^{2}-10^{5}$ virions per droplet from the infected patient. If the infected person wore rhamnolipid coated masks, almost all those viruses would be killed inside the mask coated with $0.005 \% 222 \mathrm{~B}$. Our contact study was performed on only $\sim 1 \mathrm{~cm}^{2}$ surface. A regular mask will have a large surface, which could have more kill capacity than we observed within a $1 \mathrm{~cm}^{2}$ surface. A mask coated with either $0.005 \%$ or $0.009 \%$ 222B would eliminate most of the viruses shed from an acutely infected person, which could limit the emission of viruses from the infected person and stopping the spread of diseases. Rhamnolipids are very stable on the coated surface. 222B coated on plastic remained active for as long as six months.

We have lived with the COVID-19 pandemic for almost a year, where mask-wearing, social distancing, and business shutdown have not entirely stopped the spread of the disease. The key to preventing transmission is eliminating the emission of SARS-CoV2 from an infected person and stopping the virus from propagating in the human population. The best way to stop emissions is to prevent an infected person from shedding infectious viruses to the environment. If we could have all the COVID-19 patients wearing 222B coated masks, 222B could kill most of the viruses shed in nasal or oral secretions and prevent the spread of this disease. During quarantine, if we would all use 222B coated masks, it could break the transmission chain and end the infection within short time, which will prevent the business and school from shutting down we experienced in 2020. The widespread use of 222B coated masks could end the COVID-19 pandemic much sooner 
if we implement masks that can kill viruses. Therefore, there is an urgent need to apply rhamnolipids or similar products to masks or make 222B coated masks available to the public to stop the pandemic of COVID-19.

\section{Conclusions}

In summary, this study demonstrated that rhamnolipids have antiviral activity against enveloped viruses. Many respiratory viruses are enveloped viruses, such as SARS-CoV2, influenza viruses. Rhamnolipids can kill enveloped viruses in solution (liquid phase) and on the coated surface. Direct contact with rhamnolipids can destroy the envelopes within five minutes. Rhamnolipids, 222B at $0.005 \%-0.009 \%$ can kill $\sim 1 \times 10^{4}-1 \times 10^{6} \mathrm{PFU} / \mathrm{mL}$ of enveloped viruses in solution, $1 \times 10^{3}-10^{5} \mathrm{PFU} / \mathrm{cm}^{2}$ enveloped viruses on $\sim 1 \mathrm{~cm}^{2}$ surface, respectively. The application of rhamnolipids $222 \mathrm{~B}$ on masks could help us stop the emission of viruses from the infected person, break the transmission chain, and end the pandemic of COVID-19 in weeks.

Author Contributions: Conceptualization, L.J.; methodology, L.J., W.B., and T.S.; software, L.J.; validation, L.J., W.B. and T.S.; formal analysis, L.J.; investigation, L.J.; resources, L.J.; data curation, L.J.; writing—original draft preparation, L.J.; writing—review and editing, L.J. and W.B.; visualization, L.J; supervision, L.J.; project administration, L.J.; funding acquisition, L.J. All authors have read and agreed to the published version of the manuscript.

Funding: This research received no external funding. The research was funded by Department of Biomedical Sciences, Carlson College of Veterinary Medicine, Oregon State University.

Acknowledgments: We thank AGAE Technologies, LLC (Corvallis, Oregon, USA) for production of rhamnolipids used in this study. We also thank George Rohrmann for helping editing this manuscript.

Conflicts of Interest: The authors declare no conflict of interest. The funders had no role in the design of the study; in the collection, analyses, or interpretation of data; in the writing of the manuscript, or in the decision to publish the results.

\section{References}

1. Heerklotz, H. Interactions of surfactants with lipid membranes. Q. Rev. Biophys. 2008, 41, 205-264. [CrossRef]

2. Jahan, R.; Bodratti, A.M.; Tsianou, M.; Alexandridis, P. Biosurfactants, natural alternatives to synthetic surfactants: Physicochemical properties and applications. Adv. Colloid Interface Sci. 2020, 275, 102061. [CrossRef]

3. Madrid, F.; Rubio-Bellido, M.; Morillo, E. Extraction of nonylphenol, pyrene and phenanthrene from sewage sludge and composted biosolids by cyclodextrins and rhamnolipids. Sci. Total Environ. 2020, 715, 136986. [CrossRef]

4. Kaskatepe, B.; Yildiz, S. Rhamnolipid Biosurfactants Produced by Pseudomonas Species. Braz. Arch. Biol. Technol. 2016, 59, e16160247. [CrossRef]

5. Arima, K.; Kakinuma, A.; Tamura, G. Surfactin, a crystalline peptidelipid surfactant produced by Bacillus subtilis: Isolation, characterization and its inhibition of fibrin clot formation. Biochem. Biophys. Res. Commun. 1968, 31, 488-494. [CrossRef]

6. Jarvis, F.G.; Johnson, M.J. A glyco-lipid produced by Pseudomonas aeruginosa. J. Am. Chem. Soc. 1949, 71, 4124-4126. [CrossRef]

7. Satpute, S.K.; Bhuyan, S.S.; Pardesi, K.R.; Mujumdar, S.S.; Dhakephalkar, P.K.; Shete, A.M.; Chopade, B.A. Molecular genetics of biosurfactant synthesis in microorganisms. Adv. Exp. Med. Biol. 2010, 672, 14-41.

8. Hošková, M.; Ježdík, R.; Schreiberová, O.; Chudoba, J.; Šír, M.; Čejková, A.; Masák, J.; Jirků, V.; Řezanka, T. Structural and physiochemical characterization of rhamnolipids produced by Acinetobacter calcoaceticus, Enterobacter asburiae and Pseudomonas aeruginosa in single strain and mixed cultures. J. Biotechnol. 2015, 193, 45-51. [CrossRef] [PubMed]

9. Twigg, M.S.; Tripathi, L.; Zompra, A.; Salek, K.; Irorere, V.U.; Gutierrez, T.; Spyroulias, G.A.; Marchant, R.; Banat, I.M. Identification and characterisation of short chain rhamnolipid production in a previously uninvestigated, non-pathogenic marine pseudomonad. Appl. Microbiol. Biotechnol. 2018, 102, 8537-8549. [CrossRef] [PubMed]

10. Lourith, N.; Kanlayavattanakul, M. Natural surfactants used in cosmetics: Glycolipids. Int. J. Cosmet. Sci. 2009, 31, 255-261. [CrossRef] [PubMed]

11. Campos, J.M.; Stamford, T.L.; Sarubbo, L.A.; de Luna, J.M.; Rufino, R.D.; Banat, I.M. Microbial biosurfactants as additives for food industries. Biotechnol. Prog. 2013, 29, 1097-1108. [CrossRef]

12. Lopez-Prieto, A.; Vecino, X.; Rodriguez-Lopez, L.; Moldes, A.B.; Cruz, J.M. A Multifunctional Biosurfactant Extract Obtained from Corn Steep Water as Bactericide for Agrifood Industry. Foods 2019, 8, 410. [CrossRef]

13. Sen, S.; Borah, S.N.; Bora, A.; Deka, S. Production, characterization, and antifungal activity of a biosurfactant produced by Rhodotorula babjevae YS3. Microb. Cell Fact. 2017, 16, 95. [CrossRef] 
14. Borah, S.N.; Goswami, D.; Sarma, H.K.; Cameotra, S.S.; Deka, S. Rhamnolipid Biosurfactant against Fusarium verticillioides to Control Stalk and Ear Rot Disease of Maize. Front. Microbiol. 2016, 7, 1505. [CrossRef] [PubMed]

15. Panchal, N.; Kaur, M.; Tharmatt, A.; Thakur, S.; Jain, S.K. Development, Characterization and Evaluation of Parenteral Formulation of Diclofenac Sodium. AAPS PharmSciTech 2020, 21, 219. [CrossRef]

16. Vecino, X.; Devesa-Rey, R.; Cruz, J.M.; Moldes, A.B. Evaluation of biosurfactant obtained from Lactobacillus pentosus as foaming agent in froth flotation. J. Environ. Manag. 2013, 128, 655-660. [CrossRef]

17. Mujumdar, S.; Joshi, P.; Karve, N. Production, characterization, and applications of bioemulsifiers (BE) and biosurfactants (BS) produced by Acinetobacter spp.: A review. J. Basic Microbiol. 2019, 59, 277-287. [CrossRef] [PubMed]

18. Basak, G.; Das, D.; Das, N. Dual role of acidic diacetate sophorolipid as biostabilizer for ZnO nanoparticle synthesis and biofunctionalizing agent against Salmonella enterica and Candida albicans. J. Microbiol. Biotechnol. 2014, 24, 87-96. [CrossRef] [PubMed]

19. Saif, L.J. Bovine respiratory coronavirus. Vet. Clin. N. Am. Food Anim. Pract. 2010, 26, 349-364. [CrossRef] [PubMed]

20. Dhull, D.; Sharma, V.; Sharma, Y.; Kaushik, S. Applicability of molecular assays for detection and typing of herpes simplex viruses in encephalitis cases. Virusdisease 2019, 30, 504-510. [CrossRef]

21. Patoulias, D.; Gavriiloglou, G.; Kontotasios, K.; Tzakri, M.; Keryttopoulos, P.; Koutras, C. HSV-1 Encephalitis: High Index of Clinical Suspicion, Prompt Diagnosis, and Early Therapeutic Intervention Are the Triptych of Success-Report of Two Cases and Comprehensive Review of the Literature. Case Rep. Med. 2017, 2017, 5320839. [CrossRef]

22. Moerdyk-Schauwecker, M.; Stein, D.A.; Eide, K.; Blouch, R.E.; Bildfell, R.; Iversen, P.; Jin, L. Inhibition of HSV-1 ocular infection with morpholino oligomers targeting ICP0 and ICP27. Antivir. Res. 2009, 84, 131-141. [CrossRef]

23. Jones, C. Herpes simplex virus type 1 and bovine herpesvirus 1 latency. Clin. Microbiol. Rev. 2003, 16, 79-95. [CrossRef] [PubMed]

24. Elshikh, M.; Moya-Ramírez, I.; Moens, H.; Roelants, S.; Soetaert, W.; Marchant, R.; Banat, I. Rhamnolipids and lactonic sophorolipids: Natural antimicrobial surfactants for oral hygiene. J. Appl. Microbiol. 2017, 123, 1111-1123. [CrossRef] [PubMed]

25. Gaur, V.K.; Tripathi, V.; Gupta, P.; Dhiman, N.; Regar, R.K.; Gautam, K.; Srivastava, J.K.; Patnaik, S.; Patel, D.K.; Manickam, N. Rhamnolipids from Planococcus spp. and their mechanism of action against pathogenic bacteria. Bioresour. Technol. 2020, 307, 123206. [CrossRef]

26. Radlinski, L.; Rowe, S.E.; Kartchner, L.B.; Maile, R.; Cairns, B.A.; Vitko, N.P.; Gode, C.J.; Lachiewicz, A.M.; Wolfgang, M.C.; Conlon, B.P. Pseudomonas aeruginosa exoproducts determine antibiotic efficacy against Staphylococcus aureus. PLoS Biol. 2017, 15, e2003981. [CrossRef]

27. Watson, G.; Xu, W.; Reed, A.; Babra, B.; Putman, T.; Wick, E.; Wechsler, S.; Rohrmann, G.; Jin, L. Sequence and comparative analysis of the genome of HSV-1 strain McKrae. Virology 2012, 433, 528-537. [CrossRef] [PubMed]

28. Jin, L.; Perng, G.-C.; Mott, K.R.; Osorio, N.; Naito, J.; Brick, D.J.; Carpenter, D.; Jones, C.; Wechsler, S.L. A herpes simplex virus type 1 mutant expressing a baculovirus inhibitor of apoptosis gene in place of latency-associated transcript has a wild-type reactivation phenotype in the mouse. J. Virol. 2005, 79, 12286-12295. [CrossRef] [PubMed]

29. Eide, K.; Moerdyk-Schauwecker, M.; Stein, D.A.; Bildfell, R.; Koelle, D.M.; Jin, L. Reduction of herpes simplex virus type-2 replication in cell cultures and in rodent models with peptide-conjugated morpholino oligomers. Antivir. Ther. 2010, 15, 1141-1149. [CrossRef]

30. L'Haridon, R.; Scherrer, R.; Vautherot, J.F.; La Bonnardiere, C.; Laporte, J.; Cohen, J. Adaptation of an isolate of bovine enteritic coronavirus to serial growth in cell culture and characterization of the virus (author's transl). Ann. Rech. Vet. 1981, 12, $243-251$.

31. Jin, L.; Cebra, C.K.; Baker, R.J.; Mattson, D.E.; Cohen, S.A.; Alvarado, D.E.; Rohrmann, G.F. Analysis of the genome sequence of an alpaca coronavirus. Virology 2007, 365, 198-203. [CrossRef] [PubMed]

32. Jin, L.; Lohr, C.V.; Vanarsdall, A.L.; Baker, R.J.; Moerdyk-Schauwecker, M.; Levine, C.; Gerlach, R.F.; Cohen, S.A.; Alvarado, D.E.; Rohrmann, G.F. Characterization of a novel alphaherpesvirus associated with fatal infections of domestic rabbits. Virology 2008, 378, 13-20. [CrossRef] [PubMed]

33. Finberg, R.W.; Lanno, R.; Anderson, D.; Fleischhackl, R.; van Duijnhoven, W.; Kauffman, R.S.; Kosoglou, Y.; Vingerhoets, J.; Leopold, L. Phase 2b Study of Pimodivir (JNJ-63623872) as Monotherapy or in Combination With Oseltamivir for Treatment of Acute Uncomplicated Seasonal Influenza A: TOPAZ Trial. J. Infect. Dis. 2019, 219, 1026-1034. [CrossRef] [PubMed]

34. Liu, W.-D.; Chang, S.-Y.; Wang, J.-T.; Tsai, M.-J.; Hung, C.-C.; Hsu, C.-L.; Chang, S.-C. Prolonged virus shedding even after seroconversion in a patient with COVID-19. J. Infect. 2020, 81, 318-356. [CrossRef]

35. Ogimi, C.; Kim, Y.J.; Martin, E.T.; Huh, H.J.; Chiu, C.H.; Englund, J.A. What's New with the Old Coronaviruses? J. Pediatr. Infect. Dis. Soc. 2020, 9, 210-217. [CrossRef]

36. Corman, V.M.; Albarrak, A.M.; Omrani, A.S.; Albarrak, M.M.; Farah, M.E.; Almasri, M.; Muth, D.; Sieberg, A.; Meyer, B.; Assiri, A.M.; et al. Viral Shedding and Antibody Response in 37 Patients With Middle East Respiratory Syndrome Coronavirus Infection. Clin. Infect. Dis. 2016, 62, 477-483. [CrossRef]

37. Huang, J.-T.; Ran, R.-X.; Lv, Z.-H.; Feng, L.-N.; Ran, C.-Y.; Tong, Y.-Q.; Li, D.; Su, H.-W.; Zhu, C.-L.; Qiu, S.-L.; et al. Chronological Changes of Viral Shedding in Adult Inpatients with COVID-19 in Wuhan, China. Clin. Infect. Dis. 2020, 71, 2158-2166. [CrossRef]

38. Liu, Y.; Chen, X.; Zou, X.; Luo, H. A severe-type COVID-19 case with prolonged virus shedding. J. Formos. Med. Assoc. 2020, 119, 1555-1557. [CrossRef] 